\title{
The Great Reform Act and the Modernization of British Politics: The Impact of Conservative Associations, 1835-1841
}

\author{
Matthew Cragoe
}

W hen did nationally based party alignments become significant at the grassroots of British politics? The issue has divided historians. For some, the dramatic rise in contested elections following the Great Reform Act, and the unprecedented partisanship of the enlarged electorate, suggest a real modernization of British politics in the 1830s. ${ }^{1}$ John Philips, for example, has argued that the measure "helped orient popular politics more consistently around national issues," and Frank O'Gorman and Philip Salmon have both pointed to the way in which the system of annual voter registration introduced in 1832 worked toward a similar end: not only did local parties develop new machinery to deal with registration, but their annual canvass of those eligible for the franchise, in Salmon's words, "brought the agency of party into every elector's home and . . . the politics of Westminster much closer to the electorate." "By

Matthew Cragoe is professor of modern history at the University of Hertfordshire. Having written widely on nineteenth-century electoral culture and the twentieth-century Conservative Party, he is currently leading a project that explores the cultural dimensions of parliamentary enclosure and landscape change in the English midlands, 1700-1900. The author would like to thank Paul Readman, Rohan MacWilliam, and the JBS's anonymous referees for their constructive comments on an earlier draft of this article.

${ }^{1}$ Derek Beales suggests that while the number of electors rose by 50 percent, the number of active voters increased by 200-500 percent ("The Electorate before and after 1832: The Right to Vote, and the Opportunity," Parliamentary History 11, no. 1 [1992]: 139-50); see also Frank O'Gorman, "Reply: The Electorate before and after 1832," Parliamentary History 12, no. 2 (1993): 179.

${ }^{2}$ John Phillips, The Great Reform Bill in the Boroughs: English Electoral Behaviour, 1818-1841 (Oxford, 1992), 10; O’Gorman, "Reply," 179; Philip J. Salmon, Electoral Reform at Work: Local Politics and National Parties, 1832-1841 (Woodbridge, 2002), 40; John Prest, Politics in the Age of Cobden (London, 1977); Edwin Jaggard, Cornwall Politics in the Age of Reform, 1790-1885 (London, 1999); Matthew Cragoe, Culture, Politics and National Identity in Wales, 1832-86 (Oxford, 2004); Richard W. Davis, Political Change and Continuity, 1760-1885: A Buckinghamshire Study (Newton Abbot,

Journal of British Studies 47 (July 2008): 581-603

(C) 2008 by The North American Conference on British Studies.

All rights reserved. 0021-9371/2008/4703-0008\$10.00 
bringing individual voters face to face with political realities on a regular basis," he goes on, this process generated the partisanship measured by Philips. ${ }^{3}$ Taken together, such evidence suggests that the Reform Act had a profound impact, tying the localities into an increasingly national political debate.

Yet many remain unconvinced. Miles Taylor has suggested that Philips's technique of measuring partisanship from electoral poll books is anachronistic, since it implies a level of individual choice that electors-whom even the reformed system expected to vote collectively as representatives of "interests" - did not in reality possess. ${ }^{4}$ Moreover, he insists that the penetration of "national" political identities after 1832 remained limited: local election campaigns, as James Vernon also noted, often eschewed "Westminster-based national parties" in favor of "colours, individual leaders, and even particular symbols like flowers." The Great Reform Act thus changed little. Money and influence, rather than ideology, still dominated the political world. A local election remained, as John Vincent once wrote, more "a drama enacted about the life of the town, the precedence, 'pecking order', and social sanctions which held it together, than a means of expressing individual opinions about the matters of the day." Only in the 1860s, with what Vincent described as the "sudden adoption by provincial society of the official parties as the expressions of their political feelings," did a recognizably modern politics emerge. $^{7}$

In this article, the importance of national political identities during the $1830 \mathrm{~s}$ will be restated. Rather than focus again on politics during the period of an election campaign, however, it will take soundings in what one contemporary described as "the cooler times of thought and reflection" when no contest was afoot. ${ }^{8}$ Its focal point will be the activities of the many Conservative Associations that sprang into life after the unexpected return to office of Sir Robert Peel in the winter of 1834-35. The associations worked to ensure that sympathetic voters were registered and acted as rallying points for the Conservative cause in their respective localities, educating opinion through the distribution of propaganda and strengthening political partisanship through a range of social networks. As will be seen, the Conservative Associations transcended their highly localized origins and spheres of influence and aligned themselves closely with the ideas and personalities of Westminster-based Conservatism; the result was that, in the later 1830s, grass-

1972), 103; Frank O'Gorman, "Campaign Rituals and Ceremonies: The Social Meaning of Elections in England, 1780-1860," Past and Present, no. 135, pt. 1 (1992): 113.

${ }^{3}$ Salmon, Electoral Reform at Work, 2.

${ }^{4}$ Miles Taylor, "Interest, Parties and the State: The Urban Electorate in England, c. 1820-72," in Party, State and Society: Electoral Behaviour in Britain since 1820, ed. Jon Lawrence and Miles Taylor (Aldershot, 1997), 68.

${ }^{5}$ James Vernon, Politics and the People: Study in English Political Culture, c. 1815-1867 (Cambridge, 1993), 163-64.

${ }^{6}$ John Vincent, The Formation of the British Liberal Party, 1857-1868 (London, 1966), xv; Vernon, Politics and the People, 89; Norman Gash, Politics in the Age of Peel: A Study in the Technique of Parliamentary Representation, 1830-50 (London, 1953), xxv; Thomas J. Nossiter, Influence, Opinion and Political Idioms in Reformed England: Case Studies from the North-East, 1832-74(Hassocks, 1975), 2 .

${ }^{7}$ Vincent, Formation, xxxiii.

${ }^{8}$ The Times, 11 May 1835 (meeting at E. Norfolk; speech of Mr. Praed). 
roots Conservatives were embedded in a culture of political belonging focused on national issues.

The article is divided into three sections. The first explores the political context within which the Conservative Associations formed and examines the wide range of groups attracted by their central promise to uphold what in contemporary parlance was always referred to as the "constitution in church and state." The second section then offers an account of the social activities engaged in by the local associations and explores the symbolic languages employed at key gatherings such as anniversary dinners. The final section turns to the symbiotic relationship between the associations and the press in the 1830s and examines the ways in which newspaper coverage turned the scattered opponents of the Whigs' increasingly radical reform program into a national movement, conscious of its own dimensions and armed with a standardized rhetoric available to both national and local politicians. The article concludes with a consideration of the extent to which British politics really had been modernized by the Great Reform Act.

Conservative Associations became a near-universal feature of local political life in the later 1830s. Although no formal inventory of their number was ever taken, it is likely that most constituencies could boast at least one. In Kent, for example, there were Conservative Associations in the constituencies of Sandwich, Canterbury, Dover, Margate, Deal, Maidstone, Rochester, Ramsgate, Blackheath, and Gravesend by the end of 1837, and most other counties could tell a similar tale.' In many towns-including Leeds, Manchester, Leicester, Nottingham, and Liverpool-operative associations were run alongside the parent institution. ${ }^{10}$ The new bodies were clearly heirs to a long tradition of political socialization stretching back into the mid-eighteenth century; in their local origins, the heterogeneous social composition of their membership, and their love of political debate, they resembled closely the clubs and societies that were characteristic of political life in many Georgian towns. ${ }^{11}$ The associations of the 1830s were, however, the products of a distinct time and a particular set of circumstances.

The immediate roots of the new Conservative Associations lay in the new system of annual voter registration introduced by the Reform Act in 1832. Henceforth, only those whose names were included on the register of electors could vote in an election. Given the relatively small number of eligible persons who troubled to qualify in the years after 1832, it was perhaps unsurprising that local activists on both sides should ultimately take upon themselves the responsibility for ensuring that their own supporters were registered. ${ }^{12}$ Yet, initially, there were substantial

\footnotetext{
${ }^{9}$ Kentish Gazette, 15 February, 14 and 28 April, 5 May 1835, 21 June 1836; D. M. Smith to Lord Marsham, 8 December 1837, U1515, L30, Centre for Kentish Studies (CKS), Maidstone.

${ }^{10}$ For operative associations, see Richard L. Hill, Toryism and the People (Philadelphia, 1975), 32-58.

${ }^{11}$ Kathleen Wilson, The Sense of the People: Politics, Culture and Imperialism in England, 1715-1785 (Cambridge, 1995), 61-73; Frank O'Gorman, Voters, Patrons and Parties: The Unreformed Electoral System of Hanoverian England, 1734-1832 (Oxford, 1989), 289-91. There was no concerted attempt at central control of the new associations on the Conservative side, unlike with the Whigs, although see Nottingham Journal, 24 June 1836.

${ }^{12}$ Salmon, Electoral Reform at Work, 24-28.
} 
barriers in the way of such a development; many party grandees-Peel, Wellington, and Stanley included-were highly suspicious of the new bodies. ${ }^{13}$ Recalling the role played by political unions during the reform crisis, the Honorable $\mathrm{H}$. R. Kenyon spoke for many when he worried publicly that such extraparliamentary organizations "might seem to intrench $[$ sic $]$ on a fair representative government or its monarchy." " Only an emergency of the first magnitude could override such latent hostility.

It arrived in November 1834, when William IV effectively redefined the politics of the reform decade by dismissing his Whig ministers and inviting Peel to form an administration in their stead. ${ }^{15}$ The king's action opened the door for a new alliance between the scattered remnants of the Tory party and Whiggish moderates. The latter, though they had supported parliamentary reform, now distrusted Melbourne's government; its growing dependence on the votes of radicals and Irish Catholics seemed to threaten the House of Lords and the Church, notably in Ireland. On the eve of the election, Peel sought to woo this disaffected group with his Tamworth Manifesto. He accepted that the best way to preserve the central institutions in church and state was to admit and remedy "proven abuses" and "real grievances"; equally, he insisted that any such remedies be effected "in a friendly temper" so that the institutions themselves might be rendered effective and thus serve the purpose for which they had originally been created. ${ }^{16}$ It was a message that carried an unmistakable echo of the Whigs' justification of the Reform Bill itself: "Reform that ye may preserve." 17

The election saw the return of approximately one hundred additional "conservatives," as members of the new, defensive alliance increasingly styled themselves. ${ }^{18}$

\footnotetext{
${ }^{13}$ Arthur Wellesley, 1st Duke of Wellington, to Rev. G. R. Gleig, 4 July 1831, Wellington MSS, WP1/1191/4, Southampton University Library; The Times, 29 January 1833, 5, for the detailed views of Lord Coventry; Salmon, Electoral Reform at Work, 51-53; Leicester Herald, 27 June 1835, 2; Kentish Gazette, 23 June 1835. Peel regularly declined to attend dinners given by the new associations. Belfast News-Letter, 15 May 1835 (Westminster Association), Ipswich Journal, 9 and 16 April 1836 (City of London).

${ }^{14}$ The Times, 2 September 1836 (Denbighshire). The Kentish Observer summed up the general feeling when it asked (9 May 1833), "are the Unions to govern the Government, or is the Government to govern the Unions?" and the kernel of this sentiment informed frequent reservations about Conservative Associations thereafter. The Times, 2 October 1835 (N. Lancashire; Hesketh); The Times, 27 January 1837 (N. Warwickshire; Dugdale); The Times, 31 October 1838 (Aberdeen; Ross); David Pennant to Frederick Philips, draft, n.d., but probably 5-6 July 1835, Feilding MSS, CR 2017/TP435/19, Warwickshire County Record Office (WCRO).

${ }^{15}$ Richard Brent, Liberal Anglican Politics: Whiggery, Religion and Reform, 1830-1841 (Oxford, 1987); Jonathan Parry, The Rise and Fall of Liberal Government in Victorian Britain (London, 1993); Peter Mandler, Aristocratic Government in the Age of Reform: Whigs and Liberals, 1830-1852 (Oxford, 1990), 166.

${ }^{16}$ Norman Gash, "Tamworth," in his Pillars of Government and Other Essays on State and Society c.1770-c.1880 (London, 1986); Anne Sturges Bourne to Marianne Dyson, 23 December 1834, 9M55/ F12/23, Hampshire Record Office, suggests that even women were assumed to have read it.

${ }^{17}$ The phrase was Thomas Macaulay's, and G. O. Trevelyan records that Peel thought portions of that speech "were as beautiful as anything I have ever heard or read" (The Life and Letters of Lord Macaulay, 2 vols. [London, 1876], 1:172). One might adapt Macaulay's speech and suggest that Peel's whole career from 1828 to 1846 is encapsulated in the dictum "in order to preserve what it is necessary to preserve, we must sacrifice that which it may be safe to sacrifice."

${ }^{18}$ Thus differentiating themselves from the "destructives," that is, Whigs, Radicals, and Irish. Blackwood's Edinburgh Magazine 38 (February 1835), 430; The Times, 21 September 1837, 5 (N. Wiltshire; Burdett); The Times, 9 November 1837, 1 (N. Warwickshire; Lufford).
} 
While this was insufficient to sustain Peel's fledgling administration, the nature of the victories themselves alerted sharp-eyed activists in the constituencies to the ultimate means of their party's salvation. For it emerged that the Conservatives owed their unexpected success in the Liverpool and South Lancashire county seats, among others, to the previously unheralded work of voter registration. ${ }^{19}$ The editor of Blackwood's Edinburgh Magazine, Archibald Alison, seized the moment and argued that the "battle for the constitution" was to be fought in the registration courts. ${ }^{20}$ Throughout the early months of 1835 , Conservative Associations sprang up across the country to carry this vision into effect. ${ }^{21}$

The new associations were to play a major part in the Conservative revival that followed, a resurgence that saw Peel's party attain near parity at the general election of 1837 and return to office four years later with a majority of seventy-two. Throughout the period between 1835 and 1841, the associations' outlook was defined by the political crisis that had brought them into being. In a very real sense their role was to service the grassroots of the new "Conservative" alliance between Tories and moderate Whigs that had sprung up in defense of the constitution in church and state. Significantly, the message of Peel's Tamworth Manifesto came to be enshrined in many of the constitutions adopted by the new bodies. ${ }^{22}$ The Blackheath Association, for example, acknowledged Peel's inspiration directly, suggesting that "although in all human institutions abuses will creep in, and improvements may be made, it is our firm conviction, to use the emphatic words of Sir Robert Peel, 'that it is possible to combine with the maintenance of ancient institutions and respect for established rights, the redress of real grievances, the correction of acknowledged abuses, the pure administration of public patronage, and a wise economy in the control of public expenditure." ${ }^{23}$ The Gravesend Association took the trouble to welcome the assurance of the party leader that the "spirit of the reform act" would be honored by those who enlisted under the Conservative banner. ${ }^{24}$ The Conservative Association founded for the Rape of Hastings pledged itself to support carefully considered reforms and suggested that

\footnotetext{
${ }^{19}$ The Times, 26 January 1835, 3 (S. Lancashire).

20 "Change of Ministry," Blackwood's Edinburgh Magazine 38, no. 235 (May 1835): 813.

${ }^{21}$ Norman Gash, "The Organisation of the Conservative Party, 1832-46: II," Parliamentary History 2 (1983): 131-52. Derek Beales points out that the adoption of the term "reform" by Peel for fundamentally conservative purposes rendered it useless for those who felt radical reconstruction of the constitution was necessary ("The Idea of Reform in British Politics, 1829-1850," Proceedings of the British Academy 100 [1999]: 168-71). Local Conservative Associations often adopted the declarations of neighboring bodies. (David Pennant to Frederick Philips, draft, n.d., but probably 5-6 July 1835, Feilding MS, CR 2017/TP435/19, WCRO). The Warwickshire Conservatives adapted the Derbyshire declaration (Thomas Charles Bellingham to Lord Ashburnham, 17 May 1835, Ashburnham MS 3259, East Sussex Record Office [ESRO]). Hastings Conservatives adopted the city of London declaration.

${ }^{22}$ Robert Stewart, The Foundation of the Conservative Party, 1830-1867 (London, 1978), 128-36; Gash, "Organisation of the Conservative Party," 146. Peel's role was thus more influential than some modern scholars have been prepared to admit, a topic I propose to pursue elsewhere. Ian Newbould, "Sir Robert Peel and the Conservative Party, 1834-41; A Study in Failure?" English Historical Review 98, no. 387 (April 1983): 529-57; Edwin Jaggard, “The 1841 British General Election: A Reconsideration," Australian Journal of Politics and History 30, pt. 1 (1984): 99-114; Boyd Hilton, A Mad, Bad and Dangerous People: England, 1783-1846 (Oxford, 2006), 506.

${ }^{23}$ Blackheath Polling District and Borough of Greenwich Conservative Association (Greenwich, 1835), resolution 3.

${ }^{24}$ Cited in Derbyshire Mercury, 4 February 1835.
} 
the system of tithe could profitably be revisited. ${ }^{25}$ If few associations were so specific, almost all those founded in the aftermath of the 1835 election identified themselves closely with the formula set out by Peel in his Tamworth address. ${ }^{26}$

In keeping with their fundamentally negative goals, the associations also developed a view of themselves as essentially apolitical bodies, an attitude doubtless encouraged by the sensitivities of many leaders concerning the propriety of extraparliamentary bodies interfering in politics noted above. None of the local activists gathered at Southampton to found the South Hampshire Conservative Society in 1835 , for example, found anything peculiar in the reflection of a local solicitor that there was in the name "nothing from which any one can infer the remotest tinge of a political union." 27 Rather, supporters conceived the movement as a broad alliance of people associated solely to defend the constitution in church and state. The Earl of Darlington, himself a convert from Whiggery, made this clear to a 1,500-strong Lincolnshire audience in $1837 .{ }^{28}$ "Conservatism, strictly speaking, was the union of different parties who, previously to the passing of the Reform Bill, entertained different shades of political opinion on several liberal and popular questions now passed into law; but those measures being passed, cordially united to oppose fastidious demagogues and Popish agitators who aimed at the entire subversion of every remaining institution of the country. (Cheers.) Assailed by a common enemy, they forget minor differences, and united for one common object - to preserve our venerable constitution, as established by law, in church and state. (Cheers.)." He went on to identify within the Conservative "phalanx" ultra Tories, liberal Tories, and constitutional Whigs, and many other speakers reflected in similar terms on the composite nature of Conservatism in the mid1830 s. $^{29}$

Converts to the phalanx were numerous in the years after 1835. At a national level, the most famous recruits to the Conservative cause were Sir James Graham and Lord Stanley, both of whom resigned from the Cabinet that had passed the Reform Act in protest at the planned reform of the Irish Church in 1834 and thereafter moved closer to Peel. ${ }^{30}$ However, Robert Stewart has calculated that at least forty-one other "moderate Whig" MPs had switched to the Conservatives by 1837 , including notable figures such as Sir Francis Burdett. ${ }^{31}$ The rapprochement was equally significant in the localities, as many county studies have made

\footnotetext{
${ }^{25}$ Thomas Charles Bellingham to Lord Ashburnham, 17 May 1835, Ashburnham MSS, 3259, ESRO.

${ }^{26}$ Messrs. Smith and Grover to Crawter, 7 May 1836, Crawter MSS, D/E Cr 105/5 A, Hertfordshire Record Office (Herts. RO); The Rules and Declaration of the Buckingham Conservative Association (Aylesbury, 1838), D/AR/6/42/9/1, Centre for Buckinghamshire Studies (CBS); "Flintshire Conservative Association," 25 June 1835, Fielden MSS, CR 2017/TP434/34, WCRO; Kentish Gazette, 14 April 1835; The Times, 5 June 1835 (S. Buckinghamshire).

${ }^{27}$ See Hampshire Advertiser, 25 April 1835; Trewman's Exeter Flying Post, 28 May 1835, for similar sentiments of the Honiton and East Devon Conservative Association.

${ }^{28}$ The Times, 14 October 1837,5 .

${ }^{29}$ See The Times, 11 May 1835, 3 (E. Norfolk; Browne); The Times, 29 August 1836, 1 (Flintshire; Hanmer); The Times, 20 October 1836, 5 (Liverpool; chairman); The Times, 31 October 1836, 2 (E. Norfolk; Wodehouse); The Times, 26 January 1841, 5 (Aylesbury; Hamilton); and Eric J. Evans, Sir Robert Peel: Statesmanship, Power and Party (London, 1991), 37-38, for similar comments from Sir John Walsh.

${ }^{30}$ Norman Gash, Sir Robert Peel: The Life of Sir Robert Peel after 1830 (London, 1972), 66-67.

${ }^{31}$ Stewart, Foundation, 108-9, 374; D. Read, Peel and the Victorians (Oxford, 1987), 75.
} 
clear. ${ }^{32}$ Of the three hundred people who sat down at the Durham Conservative Association dinner in January 1836, for example, one half were reckoned to be converts from the "Whig-Radical faction," 33 while the chairman of the Liverpool Tradesmen's Conservative Association took the opportunity of their first anniversary later that year to note with pleasure that many who had once opposed the local Conservative MP, Viscount Sandon, now numbered themselves among the association's 1,100 members. ${ }^{34}$ When forty-four new members were enrolled at the annual meeting of the Maidstone Constitutional Association in 1837, nearly all were said to have been converts from the Whigs. ${ }^{35}$ Sometimes, such men even emerged as leaders of the new bodies, as did Mr. Spooner, chairman of the Birmingham Loyal and Constitutional Association. ${ }^{36}$

The political context in which the Conservative Associations came to the fore was thus preeminently "national." This is not to argue that the local forces, which formerly dominated political business in the localities, were entirely supplantedquite the contrary. In many areas the presidency of the association was offered as a matter of course to the head of a leading landed family in the area. ${ }^{37}$ In Buckingham, the Constitutional Association inevitably had close links with the Duke of Buckingham and his family: not only were they generous subscribers, but the duke himself chaired the association's annual dinners. ${ }^{38}$ In a similar vein, the Duke of Newcastle was closely involved with the Nottingham Constitutional Club and was invited to comment on a draft of the rules proposed for another local Conservative Association prior to their adoption. ${ }^{39}$ The influence of great landowners remained real enough. Conservatives in the Rape of Hastings rapidly disavowed their earlier enthusiasm for tithe reform when the Earl of Ashburnham, upon whose support the association was counting, expressed reservations about the declaration. ${ }^{40}$

Nevertheless, the associations were never simply extensions of local aristocratic power. Their whole modus operandi reflected a new level of local involvement

\footnotetext{
${ }^{32}$ Davis, Political Change and Continuity, 127-54; Jaggard, Cornwall Politics in the Age of Reform, 101, 127; Matthew Cragoe, An Anglican Aristocracy: The Moral Economy of the Landed Estate in Carmarthenshire, 1832-95 (Oxford, 1996), 142; David Eastwood, "Contesting the Politics of Deference, 1820-60," in Lawrence and Taylor, Party, State and Society, 44. Compare Gash, Politics in the Age of Peel, 320.

${ }^{33}$ The Times, 16 January 1836, 3.

${ }^{34}$ The Times, 20 October $1836,5$.

${ }^{35}$ Kentish Gazette, 20 February 1837.

${ }^{36}$ The Times, 19 December 1835, 3. See, e.g., The Times (Ross \& Cromarty; Mann), 21 November 1836, 1; The Times, 9 November 1837, I (N. Warwickshire; Wilmot); The Times, 9 October 1835, 1 (E. Worcestershire; Brown).

${ }^{37}$ Thomas Charles Bellingham to Lord Ashburnham, 18 April 1835, Ashburnham MSS 3257, ESRO; the Marquis of Bute became president of the Banbury Conservative Association (Jackson's Oxford Journal, 16 May 1835), and Earl Howe of the Association at Ashby de la Zouche (Derby Mercury, 15 November 1837).

${ }^{38}$ Registers of members and subscriptions to the Buckingham Conservative Association, 1837-43, D/AR/6/1-2, CBS.

${ }^{39}$ Edward Woollett Wilmot to Henry Pelham-Clinton, 4th Duke of Newcastle, n.d. [December 1838?], Newcastle MSS, Ne C 7766, Nottingham University Library (NUL).

${ }^{40}$ Thomas Charles Bellingham to Lord Ashburnham, 19 May 1835, Ashburnham MSS 3260, ESRO; Thomas Frewen Turner to Lord Ashburnham, 18 April 1835, Ashburnham MSS 3257; Lord Camden to Lord Ashburnham, 10 January 1837, Ashburnham MSS 3256. The general resolution in favor of useful reforms, however, remained intact. "Declaration," 20 May 1835, Frewen MSS 793, ESRO.
} 
in - even responsibility for-a national politics. Whereas the maintenance of a political "interest" prior to the Reform Act had naturally fallen on the individual landowner and his agent, the day-to-day running of the associations appears to have been a collective affair. ${ }^{41}$ In counties such as Hertfordshire, Gloucestershire, and Staffordshire, it was the resident gentry who kept the machinery running; in boroughs such as Canterbury, Southampton, and Buckingham, a middle class of lawyers, doctors, and professionals did the work; and in large towns like Liverpool, with a long history of local association for political ends, the organization appears to have sprung from and remained the organizational domain of local tradesmen. ${ }^{42}$

One practical illustration of the new political order symbolized by the associations was that many of the costs associated with local political activity were now routinely shared among the committed partisans. ${ }^{43}$ The expenses of electoral registration, for example, were met in many areas by local partisans, and one of the first tasks of any new association was to set membership fees at a level that allowed a fund to be developed for this purpose. ${ }^{44}$ At Buckingham, Conservative Association subscribers were invited to contribute between $2 \mathrm{~s}$. $6 \mathrm{~d}$. and 1 guinea, and individual donations were solicited on top of this. By 1837, it had three hundred members. ${ }^{45}$ In Nottingham, even the one-penny fee solicited from working men attending the Monday night gatherings of the Operative Conservative Association was put toward the cost of registration: the effort of returning a member to Parliament embraced all sections of the community. ${ }^{46}$ How many of those who subscribed to local registration funds (by whatever means) possessed the right to vote is not clear; many members of the Buckingham Association, for example, did not. Thomas Pearcy paid his annual subscription loyally despite being struck from the register in 1838, while Thomas Ridgeway of Hillesden, who joined on 1 January 1838 and subscribed at the rate of 5 s., was only registered for the vote in $1841 .{ }^{47}$ Given that these clubs, unlike their later nineteenth-century counter-

\footnotetext{
${ }^{41}$ For the maintenance of interests, see Matthew Cragoe, "The Golden Grove Interest in Carmarthenshire Politics, 1804-21,"Welsh History Review 16, no. 4 (1993): 467-93.

${ }^{42}$ J. Plumptre to F. W. Cobb, 15 January 1836, U1453, 095 (Bundle B), CKS; "Meeting of Freeholders" (12 August 1837), D637/I/103, Gloucester Record Office; Gash, "Organisation of the Conservative Party," 143-45; Stewart, Foundation, 130; Davis, Political Change and Continuity, 158; Richard Olney, Lincolnshire Politics, 1832-85 (Oxford, 1973), 75-77, 112; Cragoe, An Anglican Aristocracy, 150-55; Salmon, Electoral Reform at Work, 143-44. Frederick Philips to David Pennant, 23 June 1835, Fielding MS, CR 2017/TP435/10, WCRO; Frederick Philips to David Pennant, n.d. [5 July 1835], CR 2017/TP435/12, WCRO; "1834 County Election Minutes," fols. 11-12, 5 February 1835, D/EL B562, Herts. RO; Hampshire Advertiser, 25 April 1835; Salmon, Electoral Reform at Work, 143; The Times, 20 October 1836, 5; Stephen M. Lee, “The Pride of my Publick Life': George Canning and the Representation of Liverpool, 1812-1823," Transactions of the Historic Society of Lancashire and Cheshire 149 (1999): 73-98.

${ }^{43}$ C. H. Ingleby to Copner Oldfield, 14 November 1837, Fielding MS, CR 2017/TP436/38, WCRO; Sir Stephen Glynne to J. W. Eyton, 29 June [1838], CR 2017/TP436/12/1-2, WCRO; Warwick Borough Conservative Association minute book, 1837-38, CR 556/877, 878.

${ }^{44}$ Leicester Herald, 7 February 1835; Hampshire Advertiser, 25 April, 6 June 1835; Nottingham Journal, 9 December 1836.

${ }^{45}$ Jackson's Oxford Journal, 16 July 1836; Caledonian Mercury, 13 June 1835; membership of the Edinburgh Conservative Association was set at $£ 1$.

${ }^{46}$ Derbyshire Mercury, 4 January 1837.

${ }^{47}$ Buckinghamshire Registration 1841, D/AR/6/15/14i, CBS; Registers of members and subscriptions to the Buckingham Conservative Association, 1837-43, D/AR/6/1-2, CBS; "Conservative Association: Analysis Borough Registration (1838)," D/AR/6/15/2, CBS.
} 
parts, rarely provided much in the way of leisure facilities, such men seem to have made an individual decision to pay a subscription so that the register could be tended and a representative who shared their views returned, regardless of the fact that they could not themselves vote. ${ }^{48}$

Annual registration formed an expense that local Conservatives across the country seem to have been willing to bear; occasionally, unanticipated crises imposed further demands on local supporters. Conservatives in the Granby District of Leicester entered a subscription in October 1835, for example, to provide sufficient sums that two poor freemen, down on their luck, might be saved from going to the parish for relief, an action that would have disqualified them from voting. ${ }^{49}$ More dramatically, there were several instances in which local Conservatives, passionate for the success of the cause, entered subscriptions to defend a newly won seat from a hostile petition. Leicester again provides an example. The Conservatives seized both seats in the town at the election of 1835; when their opponents threatened to petition against the result, the Conservatives called an emergency meeting at which $£ 600$ was subscribed to a defense fund within one hour. ${ }^{50} \mathrm{~A}$ very similar determination gripped local Conservatives in Bridgewater two years later, when the newly elected MP, Mr. Broadwater, declared that he would not defend the seat he had won so expensively; the local partisans took upon themselves the cost of securing the seat. ${ }^{51}$ Subscriptions of this type were not always local affairs. After the 1837 election, a meeting at the London Coffee House on Ludgate Hill resolved that Dublin Protestants had spent so much in defending seats against petitions over the last two years that it was unreasonable to expect them to keep fighting the Conservative cause alone; accordingly, subscriptions were sought across the nation. The lists subsequently published in the columns of local newspapers reveal that thousands came forward, subscribing sums of up to one sovereign. ${ }^{52}$

The Conservative Associations were thus a distinctive product of the mid-1830s. The perceived crisis in national affairs ensured that popular support for the principles they espoused was forthcoming and that the demands of the new registration system became a focal point for local activism. However, the identification between local and national politics could not be taken for granted, and in the next section attention turns to the means by which the associations fostered the connection.

The range of activities undertaken by the Conservative Associations was surprisingly broad. Their primary task may have been to fight the annual battles in the registration court, but many quickly embraced a wider role, organizing peti-

${ }^{48}$ C. H. Ingleby to Copner Oldfield, 14 November 1837, Fielding MSS, CR 2017/TP436/38, WCRO; Bills of Thomas Nicks relating to parliamentary registration for the borough of Warwick, 1837-40, Campbell, Brown and Ledbrook MSS, CR 556/880, WCRO; Cragoe, Culture, Politics and National Identity, 104-5; Jon Lawrence, Speaking for the People: Party, Language and Popular Politics in England, 1867-1914 (Cambridge, 1998), 179-80.

${ }^{49}$ Leicester Herald, 10 October 1835, 8.

${ }^{50}$ Leicester Herald, 21 March 1835, 8.

${ }^{51}$ Canterbury Weekly Journal, 17 June 1837.

${ }^{52}$ Leicester Herald, 23 September 1837, 1 (advertisement). 
tioning campaigns and selecting candidates to run for local office. ${ }^{53}$ At Warwick, the Conservative Association selected and promoted suitable candidates for the town council, the Board of Guardians, and even the position of churchwarden, as all offices became caught up in the prevailing political excitement. ${ }^{54}$ In some constituencies local associations took the lead in finding candidates to run for Parliament. When both MPs for South Derbyshire intimated that they wished to retire in 1840 , for example, it fell to the committee of the local association to make initial contact with E. M. Mundy and Charles Robert Colville and then have their nominations proposed, seconded, and approved by the rank-and-file membership..$^{55}$ In Preston, it seems to have been the Operative Association that invited T. Murray Gladstone to stand for the town in $1840 .{ }^{56}$ Such involvement naturally kept up levels of local enthusiasm for the cause; however, as this section will demonstrate, Conservative Associations also invested heavily in educational and social activities in their efforts to make converts and turn the political tide.

Historians have tended to play down the cerebral challenges offered by Conservatism. In comparison with the Whig and radical platforms, for example, one recent scholar has dismissed what was on offer from the Conservative side as "a basic Church-and-Field Toryism" augmented with a splash of anti-poor law rhetoric for "the politically ignorant and ideologically uninitiated." ${ }^{57}$ Yet this underestimates the extent to which Conservatives in the 1830s recognized that they had to win a fundamental ideological argument in order to attain their political goals. The associations quickly came to be seen as the means by which the ideological battle might be carried to the enemy. As a correspondent of The Times made clear while offering his support for the formation of a City of London Conservative Association in 1835, the new body could play a vital role, "especially if founded not merely for the purpose of registration . . . but upon the broader basis of disseminating correct information on the great leading political questions of this eventful crisis." 58

This spirit ensured that education became a great concern of many Conservative Associations. In Belfast, the ambitious plans outlined by the local association in 1837 included the erection of a giant "Conservative Hall" for the province of Ulster, capable of seating two thousand diners, with additional provision for committee rooms and a public newsroom. ${ }^{59}$ In Manchester, the town's Conservative Association assisted with the creation of reading rooms for both their middle-class and operative members as they sought to ensure that "the minds of the people" were "enlightened in religious morals and sound political knowledge." ${ }^{\circ 0}$ A similar

${ }^{53}$ Kentish Gazette, 28 July 1835 (municipal corporations), 13 December 1836 (House of Lords).

${ }^{54}$ Salmon, Electoral Reform at Work, 38; Hampshire Advertiser, 26 September 1835; Leicester Herald, 26 September 1835; unpaginated MSS: entries for 23-24 November 1837, 22 March and 13, 16 April 1838, Ledbrook MS, CR 556/877, 878, WCRO. Other areas saw similar coordination. Hampshire Advertiser, 26 March 1836; Nottingham Journal, l July 1836.

${ }_{55}^{5}$ Derby Mercury, 29 April 1840. See also Leeds Mercury (Liverpool), 15 April 1837; Ipswich Journal (West Sussex), 23 September 1838; Derby Mercury (West Suffolk), 25 April 1838; Ipswich Journal (Manchester), 3 April 1841.

${ }^{56}$ According to a report in North Wales Chronicle (Bangor), 28 January 1840.

${ }^{57}$ Salmon, Electoral Reform at Work, 84 .

${ }^{58}$ The Times, 24 February 1835.

${ }^{59}$ The Times, 6 February 1837, 3.

${ }^{60}$ The Times, 24 August 1836 (Manchester Operatives); The Times, 26 August 1836 (N. Cheshire). 
situation prevailed in Nottingham. Having originally housed their reading room in premises borrowed from the Duke of Newcastle, the Constitutional Club relocated to the town's old assembly rooms in 1836 , paying $£ 1,100$ for the freehold and another $£ 1,900$ to remodel the building. ${ }^{61}$ The money was raised by selling some six hundred shares, and a breakdown of subscribers suggests that the vast majority ( 88 percent, or 138 of 156 subscribers) came from the town itself: the reading room was an urban middle-class initiative rather than something emanating from the largesse of neighboring landowners. The same class seems to have taken the lead in the various ward associations that subsequently founded reading rooms for operatives. ${ }^{62}$ Disseminating education in rural areas was somewhat more difficult, although the Buckingham Conservative Association purchased twenty-five copies of the Conservative-leaning Buckinghamshire Herald each week for distribution among the leading public houses in the surrounding villages free of charge. ${ }^{63}$ Thus whatever fears might lurk in the collective Tory imagination concerning the wisdom of placing education in the way of the populace, and particularly of its poorer members, there was a general recognition that "the appetite for knowledge" had been created and that if it were not provided with "wholesome food," it would, in its eagerness, "seize on those pernicious fruits which spring from a licentious press. $" 64$

The local associations also laid great stress on the simple power of social and convivial gatherings to further their ends. As the Canterbury Weekly Journal remarked, "the existence of such a society simplifies the conduct of an election, for it silently and steadily does the work of the hottest canvass. Men who are accustomed to meet from time to time as avowed Conservatives . . . are too deeply pledged for . . . backsliding." " In boroughs such as Canterbury, Sandwich, Leicester, and Nottingham, the central society met on a monthly basis, but in many boroughs, additional "auxiliary" bodies were established in the various wards that appeared after the Municipal Corporations Act of 1835, and these met weekly in public houses loyal to the cause. ${ }^{66}$ Sympathetic newspapers invariably carried a note indicating which house would be favored with the presence of local Conservatives in the forthcoming week. ${ }^{67}$ Meetings were reasonably formal, with a chairman, an advertised time of starting, and, sometimes, a prearranged topic for discussion; however, they were also occasions for the singing of songs, drinking of toasts, and general conviviality. ${ }^{68}$

The way in which "education" and sociability mixed can best be seen in the regular public dinners hosted by the associations. Political dining had deep roots

\footnotetext{
61 "Address to the Duke of Newcastle from the members of the Constitutional Club in Nottingham," 6 February 1833, Newcastle MSS, Ne X 3, NUL; Messrs. Leeson and Gell to Henry Pelham-Clinton, 4th Duke of Newcastle, 6 April 1833, Ne C 5038, NUL; Messrs. Leeson and Gell to Henry PelhamClinton, 4th Duke of Newcastle, 6 June 1833, Ne C 5040, NUL. Nottingham Journal, 17 June 1836.

${ }^{62}$ Nottingham Journal, 3 June 1836; Leicester Herald, 21 January 1837, 8.

${ }^{63}$ The Rules and Declaration of the Buckingham Conservative Association (Aylesbury, 1838), D/AR/ $6 / 42 / 9 / 1$, CBS. They opened a subscription for a reading room in 1838 .

${ }^{64}$ Nottingham Journal, 16 September 1836.

${ }^{65}$ Canterbury Weekly Journal, 16 October 1841.

${ }^{66}$ Leicester Herald, 7 February 1835, and 29 August 1835, 8; Nottingham Journal, 22 July 1836.

${ }^{67}$ Nottingham Journal, 27 May 1836.

${ }^{68}$ Nottingham Journal, 11 November 1836; Leicester Herald, 5 September 1835, 8; Leicester Herald, 1 April 1837, 8.
} 
in Britain; nevertheless, the scale of Conservative dining in the three years after Peel's short-lived ministry was without precedent and marked a definite rediscovery of political appetite among a group who had found very little to celebrate since their thrashing at the polls in $1832 .{ }^{69}$ As George Kitson Clark put it, the whole country suddenly "resounded with the noise of Conservative dinners, with the clink of glasses, and the clatter of knives and forks, the hubbub of dinner-table conversation now and again to be hushed for fiery denunciations of O'Connell and the Ministry, and praise for the peerage." ${ }^{70}$ Many of these events were reported in the national daily press; using evidence drawn from accounts of some 115 dinners recorded in The Times between January 1835 and February 1841, it is possible to describe in some detail the typical features of these highly stylized and ritualized occasions and to underline the extent to which national political issues dominated the horizon of grassroots Conservatism.

Conservative Association dinners were invariably held indoors and were strictly ticketed. This was explicable partly on purely administrative grounds: those preparing the meals had to know how many they were to cater for, and the committees had to cover the costs of the proceedings. ${ }^{71}$ However, at a more general level, the ticketing of Conservative Association events helped distance them from the mass meetings held by bodies like the political unions, which carried an unwelcome air of democratic menace. ${ }^{72}$ Ticketing helped guarantee respectability, and it was presumably a similar impulse that dictated another feature of these dinners: the almost entire absence of any symbolic occupations of public space by the diners, even in towns where local rivalries were keenly felt. ${ }^{73}$ It is interesting to note that the four exceptions in the sample all involve operative societies, at Howick, Chorley, and Blackburn in Lancashire, and at Pudsey in Yorkshire. ${ }^{74}$ In Blackburn, the procession

${ }^{69}$ James Epstein, "Radical Dining, Toasting and Symbolic Expression in Early Nineteenth-Century Lancashire: Rituals of Solidarity," Albion 20,pt. 2 (1988): 274-75; Peter Brett, "Political Dinners in Early Nineteenth-Century Britain: Platform, Meeting Place and Battleground," History 81, no. 264 (October 1996): 527-52.

${ }^{70}$ George Kitson Clark, Peel and the Conservative Party: A Study in Party Politics, 1832-1841, 2nd ed. (1929; repr., London, 1964), 332.

71 "1834 County Election Minutes," fols. 8-12, D/EL B562, Herts. RO; "Buckingham Conservative Association Minutes of Proceedings \&c.," 27 November 1837, 7-8; 4 December 1837, 9; 12 December 1837, 11-12; 26 December 1837, 15-17; D/AR 6/41, CBS; Sir John Chetwode to Henry Smith, 18 December 1840, D/AR/6/6/2/17, CBS; Scott Murray to H. Smith, 13 January 1845, D/AR/ $6 / 7 / 2 / 11$, CBS.

${ }^{72}$ Nancy LoPatin, Political Unions, Popular Politics and the Great Reform Act of 1832 (London, 1992), 28, 169-70. Some bodies explicitly distanced themselves from radical agitations: the Stockport Operative Conservative Association, for example, stated in their constitution that their objects were "diametrically opposite to those of the late political unions. We exist for the purpose of defending, not attacking, the institutions of the country." Quoted in "Operative Associations," The Conservative, no. 2 (1 August 1836): 9-10.

${ }^{73}$ Vernon views ticketing only as a means by which the establishment denied "the people" access to politics; however, it equally reflected the desire of both organizers and participants to appear in respectable society, a theme reflected in many other nonpolitical areas of early Victorian society (Politics and the People, 123-25, 225-30). Brenda Assael, The Circus and Victorian Society (Charlottesville, VA, 2005).

${ }^{74}$ Only in the west country does this general rule not hold true: Trewman's Exeter Flying Post, 11 August 1836 and 27 January 1837; O'Gorman, "Campaign Rituals and Ceremonies," 106-7. The Times, 3 September 1836, 5; 14 November 1836, 6; 24 November 1836, 5; 21 April 1837, 6. In 1836, the Warrington operatives draped a large flag across the front of Cloth Hall, where they met, 
marched proudly through the town carrying two banners, one presented by the wife of a local banker and the other by the "gentlemen of Blackburn," both bearing the legend "Blackburn Operative Conservative Association"; they called at the local vicarage on their way to Cloth Hall to pick up the Vicar of Blackburn, Rev. J. D. Whittaker, and Mr. William Fielden, the Conservative MP for the borough. ${ }^{75}$ In Pudsey, the members of the association marched to the Commercial Hotel, headed by a blue silk banner with the pleasingly alliterative slogan "Protestant Patriots of Pudsey" inscribed upon it, to the Commercial Hotel, every man wearing a blue rosette. ${ }^{76}$

The determinedly local identifications fostered by both the banners and the holding of such parades, however, were exceptional. Most Conservative dinners began at the appointed dining hall, where the decoration echoed their patrons' attachment to the Crown, the Church, and Parliament. The visual grammar of decorations within Conservative dining halls was remarkably consistent, with the primary positions in the room occupied by symbols bearing "national" connotations. It was commonplace, for example, to place behind the chair a legend such as "Church, King, and Constitution," or to fly the Union flag over the head of the chairman. ${ }^{77}$ The names of Conservatism's national heroes were also prominently displayed, as in the huge marquee erected for the South Lincolnshire Festival in 1837, where the names of leading Conservative statesmen were emblazoned on a splendid star suspended over the vice president's chair, or at Falmouth, where a large banner on the gallery bore the Cornish arms and the names "Wellington" and "Peel." 78 Certainly the most expensive and visually striking ornaments were all concerned with promoting the national dimension of the meeting's purpose. At the inauguration of the Devonport society in November 1836, the reporter noted that "no expense had been spared to add to the effect": over the principal entrance was a large transparency of Britannia and the British lion, and beneath them a "splendid white silk banner" in the center of which were the crown and scepter, supported by the Bible, and the motto "Fear God and Honour the King." At the western end of the room was a portrait of the king. At the West Suffolk meeting of 1836, guests entering the pavilion through the principal entrance were confronted by a "neat transparency, illuminated by Gas and surrounded by roses, featuring a crown surrounded by the words 'The King, God Bless Him." Above the president, meanwhile, was a stained glass transparency of the Royal Arms of England, and in the center of the room, immediately in front of the president, a large gilt crown, described by the reporter as "superbly lighted with gas in the form of diamonds and brilliants." ${ }^{79}$ Similarly, at the Salford meeting of 1838, where the principal guests sat at a circular table over which was a canopy ornamented

bearing the legend "Church and King," surrounded by the words "Warrington Operative Association": this was the only example of an external decoration in the sample (The Times, 27 April 1836). Many operative bodies did not parade the streets, however (Derby Mercury, 21 October 1840).

${ }^{75}$ The Times, 14 November 1836, 6.

${ }^{76}$ The Times, 21 April 1837, 6.

${ }_{77}$ The Times, 24 October 1836, 7; The Times, 3 November 1836 (Halifax); The Times, 23 September 1839, 6 (N. Northamptonshire). There were exceptions: The Times, 11 May 1835 (E. Norfolk); The Times, 17 October 1835, 3 (S. Lancashire).

${ }^{78}$ The Times, 14 October 37 (S. Lincolnshire); The Times, 4 October 1837 (Falmouth); The Times, 27 October 1836 (Leeds); The Times, 31 October 1836 (E. Norfolk).

${ }^{79}$ The Times, 15 June 1836 (W. Suffolk). 
like a military tent, a beautifully carved and gilt queen's arms hung over the chair, and opposite, at the extreme end of the pavilion, the royal cipher and imperial crown were picked out in brilliant gas jets against a blue ground. ${ }^{80}$

In contrast, slogans with a more "local" resonance-the names of local MPs, the name of the Conservative Association hosting the dinner, or the majority secured at the previous election-were either relegated to inferior positions in the room, above the chair of the vice president or along the side walls, or mediated by the national symbols mentioned above. ${ }^{81}$ The 1836 meeting of seven hundred Conservative tradesmen in Liverpool provides a good example. ${ }^{82}$ Behind the seat of the president hung a display of banners. In the center was "Our Glorious Constitution," on the left "Lords and Commons," on the right "Church and King," and beneath all three "Liverpool Tradesmen's Conservative Association." To the right of the chair was the banner of the South Lancashire Conservative Association, with its motto, "King and Constitution in Church and State," prominently displayed, while on the left of the chair waved a flag bearing the arms of James Aspinall, Conservative Mayor of Liverpool, beneath which was inscribed "King and Constitution." In this example, the local elements of the display were symbolically placed beneath the central declarations of loyalty to the greater goals pursued by Conservatives - the glorious constitution, the lords and commons, the church and king - or to the side. Even then, however, they were not unmediated, but supplemented by loyal and patriotic dicta.

The after-dinner speeches provided the principal entertainment of the evening; these, unsurprisingly, complemented the national orientation of the decorations decking the walls. ${ }^{83}$ There seems no doubt that it was the speeches rather than the food for which people came. The records of the Buckingham Conservative Association, unique in the level of detail they offer concerning this aspect of the organizations' work, contain many requests such as that addressed to the association's secretary asking for "a place at the festive Board, where I can see, hear, and learn." " There were often complaints if the management of a dinner meant that some portion of the speeches was inaudible to the diners, as apparently happened at the City of London Conservative Association meeting in 1837, when half the audience gathered at the Covent Garden Theatre could not hear what was being said. ${ }^{85}$ In the wake of the Reform Act, popular interest in national political affairs seemed unquenchable.

The running order of the speeches varied little. Diners were led inexorably through formulaic acknowledgments of the royal family and the army and navy to the three great set-piece toasts during which the heart of the Conservative case

\footnotetext{
${ }^{80}$ The Times, 19 April 1838 (Salford). See also The Times, 8 November 1836 (Devonport); The Times, 26 November 1839, 2 (Barnsley Operatives).

${ }^{81}$ The Times, 15 June 1836 (W. Suffolk); The Times, 27 October 1836 (Leeds); The Times, 9 January 1837 (N. Warwickshire); The Times, 24 October 1836 (E. Worcestershire).

${ }^{82}$ The Times, 20 October 1836 (Liverpool).

${ }^{83}$ Musical accompaniments, which appear to have been decided not by the organizers of the meeting but by the musicians themselves, have been omitted from this account. Sir John Chetwoode to Henry Smith, 18 December 1840, D/AR/6/6/2/17, CBS.

${ }^{84}$ J. Congreave to H. Smith, 19 January 1845 , D/AR/6/7/2/7, CBS; James B. Delap to H. Smith, 20 January $1844, \mathrm{D} / \mathrm{AR} / 6 / 7 / 3 / 5$, CBS.

${ }^{85}$ The Times, 10 June 1837, 5.
} 
could be elaborated and the prevailing threats to the constitution laid out in detail. The first celebrated the Church of England and highlighted the bond it represented between the nation and the Almighty: the stout opposition of the Church to Catholicism, it was repeatedly claimed, had persuaded the Deity to raise Britain to the unprecedented levels of prosperity and international preeminence she enjoyed. Whig attempts to undermine its position naturally imperiled this most sensitive of special relationships. ${ }^{86}$ The second toast, to the House of Lords, celebrated the resistance of the Upper House to the hostile legislation sent up by the Whigs and their radical allies, particularly between 1835 and 1837; their resistance was portrayed as the latest example in a tradition stretching back to the Magna Carta of the peers standing in the breach to defend the people's liberties. ${ }^{87}$ The third of the three principal toasts celebrated "Sir Robert Peel and the Conservative Members of the House of Commons." Speakers-often either MPs or prospective candidates nursing a constituency-invariably followed the distinctly "Peelite" formula enshrined in the constitutions of the associations themselves, declaring their support for the Church and the constitution and an anxiety to reform proven abuses. ${ }^{88}$ Many highlighted the simple truth that only if sufficient MPs were returned to Parliament would the reckless progress of Whig reform be halted and went on to praise the work done by the local Conservative Associations to ensure this. Where, as in Canterbury, the MP made a point of attending his association's annual registration dinner, the link between local activity and national political outcomes was forcibly made. ${ }^{89}$

The nature of the Conservative alliance ensured that those addressing such themes spent much of their time reflecting on the general merits of the constitution and the nature of the threats that assailed it, rather than rehearsing narrower grievances that might smack of "party." Audiences responded to well-understood attacks on figures such as O'Connell and, equally, to laudatory comments concerning their own leaders. Any mention of the Duke of Wellington, variously introduced as the "winner of a hundred battles" or "the foremost man of all the world," was guaranteed to elicit rapturous applause. ${ }^{90}$ At Bath in 1835, the cheering of the 750-strong audience lasted at least ten minutes, and the chairman "was obliged to request that the meeting would be somewhat shorter in their notes of

\footnotetext{
${ }^{86}$ The Times, 26 August 1836 (N. Cheshire; Hollingsworth); The Times, 19 September 1836 (E. Riding; various); The Times, 10 September 1836 (S. Lancashire; Clarke); The Times, 20 October 1836 (Liverpool Tradesmen; Sandon); The Times, 25 November 1836 (Finsbury; Pownall); John A. Golby, "A Great Electioneer and His Motives: The Fourth Duke of Newcastle," Historical Journal 8, pt. 2 (1965): 201-18; see Linda Colley, Britons: Forging the Nation, 1707-1837 (London, 1992), for the development of this worldview.

${ }^{87}$ The Times, 19 January 1837, 5; Mandler, Aristocratic Government in the Age of Reform, 166. For similar sentiments, see The Times, 12 October 1835 (S. Cheshire; Wilbraham); The Times, 14 December 1835, 1 (Sheffield); The Times, 10 September 1836, 4 (S. Lancashire; Skelmersdale); The Times, 19 September 1836, 3 (E. Riding; Coltman).

${ }^{88}$ The Times, 30 September 1835 (Worcester; Spooner); The Times, 2 October 1835 (N. Lancashire; Hesketh).

${ }^{89}$ See Kentish Gazette, 31 October 1837; Canterbury Weekly Journal, 24 November 1838, and 14 November 1840 for Bradshaw's attendance in Canterbury.

${ }^{90}$ The latter is from a speech delivered by Professor Fleming. The Times, 28 December 1839, Glasgow Peel Club.
} 
admiration." ${ }^{91}$ Peel's name was similarly received in many areas. At a meeting of the Manchester Operative Conservative Association in September 1835, for example, the curious toast "the late foreman of the lower shop, the Right Hon Sir Robert Peel" was greeted with "three times three cheers, followed by longcontinued and deafening applause," which for several minutes prevented the chairman from adding the remainder of the toast, "and the Conservative Members of Parliament." "The enthusiasm with which this toast was drunk," gushed the reporter, "surpassed everything of the kind that we ever witnessed on any former occasion." "92

Given the controversy that still surrounds Peel's success in wooing the urban middle class, it is very striking how often his name was celebrated with greater honors than that even of the duke. Three examples from Nottingham make the point. ${ }^{93}$ At the Nottingham Operative Conservative Society dinner in February 1836, the only names honored with three times three and one over were those of Peel, the president, and a local newspaper editor (the last two being present). The Duke of Wellington and the Duke of Newcastle simply got three times three. Later that year, at the Nottingham Constitutional Club annual dinner, Peel got "four times four," compared with Newcastle, Wellington, and the Royal Family, who all had to make do with the standard allocation. The only toast more popular than Peel was "Church and State," which was received with "nine times nine" and "one cheer more" sixteen times repeated! Finally, a week later, at the Waterloo dinner celebrated by Conservatives in Sneinton, the king was received with three times three, Wellington, hero of the battle, four times four, and Peel with nine times nine. In the pantheon of Conservatism's national heroes, Peel had a tremendous appeal among both middle class and operative audiences.

The toasting and speechifying might carry on long into the night. Thomas Estcourt MP recorded that he did not get home from the Bath Conservative Association dinner in 1839 until " $2 \frac{1}{2}$ in morning." to include as many as twenty separate items and to embrace local dignitaries, the prosperity of agriculture, and the health of the ladies. However, the local toasts tended to come near the bottom of the agenda: the prime part of the evening, before the company had slipped home-or simply under the table-was focused exclusively on the national context for Conservative activity, and the most prominent speakers-often invited especially for the occasion-would be detailed for this part of the proceedings. ${ }^{95}$ It was the national importance of the sentiments expressed that brought the diners together, and it was the same spirit that ensured the interest of national and local newspapers discussed in the next section.

${ }^{91}$ The Times, 12 December 1835 (Bath).

${ }_{92}$ The Times, 1 September 1835 (Manchester Operatives).

${ }^{93}$ Nottingham Journal, 5 February, 17 February, and 24 June 1836.

${ }^{94}$ Diary of T. H. S. S. Estcourt, 5 April 1839, D1571/F389, Gloucester Record Office.

${ }^{95}$ The Bacchanalian potential of these events should not be underestimated. It was reported that Captain Saunders of Glanrhydw disgraced himself at a Conservative dinner in Carmarthen, getting terribly drunk, offering to fight a member of the company, "and afterwards catting over his neighbours and doing something worse in his breeches." H. G. Williams to Herbert Evans [n.d., 1837], Highmead MSS, 2399, National Library of Wales (NLW); Kentish Herald, 26 March 1835; anonymous, Election Day: A Sketch from Nature (London, n.d. [1837?]), 22-32. "Conservative Dinner, Buckingham, January 11th, 1842. . . List of Toasts," printed list, D/AR/6/42/a/29, CBS; Duke of Buckingham to Henry Smith, n.d., but December 1841, D/AR/6/3/4, CBS. 
The development of the newspaper press in the eighteenth century was central to the "nationalisation" of political culture. As Kathleen Wilson has suggested, it helped to lift politics above its local milieu and facilitated people's "vehement engagement with national affairs." 96 The growth of Conservative Associations in the period after 1835 would have been unthinkable without the presence and support of a well-developed newspaper press: even Archibald Alison recognized that the battle for the constitution could never take place in the registration courts alone. Indeed, the first half of his famous article in Blackwood's Edinburgh Magazine urging attention to voter registration directed Conservatives to use the influence of the press in order to convince the country's "property and intelligence" that their arguments were sound. ${ }^{97}$ As this section demonstrates, it was a lead that publishers at both local and national levels were only too happy to follow.

The local newspaper press enjoyed a period of sustained growth in the 1830s. In 1800 there had been just seventy provincial titles; by 1832 this had expanded to 130 , and by the end of the decade to some two hundred. ${ }^{98}$ Few made any pretense of political neutrality; indeed, many wore their partisanship on their sleeve, casting their weekly editorials as fiery commentaries on national affairs. ${ }^{99}$ The fact that all newspapers filled their remaining columns with articles and reports copied from sympathetic journals, local and national, added to the effect: the localities were saturated with news and views about "national" politics and politicians throughout the reform decade. ${ }^{100}$ Those who ran the newspapers were often active partisans in their own right, fighting their party's cause in local and municipal elections. Investigating the ways in which their political beliefs and business interests intersected highlights the links that developed between the press and the new Conservative Associations in the period after 1835.

Two examples may be used to illustrate the point. In Canterbury, the editor of the Kentish Gazette, Henry Smithson, was the driving force behind the establishment of a Conservative Association. ${ }^{101}$ Under his aegis, the Gazette provided lavish coverage of all the association's proceedings. Direct political activity—such as registration court proceedings, corporation elections, and petitioning campaignswas naturally reported, but the newspaper also provided detailed accounts of the speeches delivered at anniversary dinners and other meetings—often in special

\footnotetext{
${ }^{96}$ Wilson, The Sense of the People, 37; David Eastwood, "Contesting the Politics of Deference," 31; O'Gorman, Voters, Patrons and Parties, 9.

97 “Change of Ministry," Blackwood's Edinburgh Magazine 38, no. 235 (May 1835): 813-14.

${ }^{98}$ Hannah Barker, Newspapers, Politics and English Society, 1695-1855 (Longman, 2000), 29.

${ }^{99}$ See "Advertisements received by Lewis \& Clarke" (1836), 2nd ed., British Library (BL), 1881.c.16, for the political affiliation of the nation's newspapers.

${ }^{100}$ Newspapers such as the Canterbury Weekly Journal devoted a specific column, entitled "The Politician," to articles from other newspapers and periodicals; others simply picked up stories as they appeared. Either way, national "news"-of, say, success across the country at the annual registrationwas actively circulated. Kentish Gazette, 10 November 1835.

${ }^{101}$ Letter of “A Freeman,” Kentish Gazette, 20 January 1835.
} 
supplements rushed out on the morning after the event or in pamphlet form. ${ }^{102}$ The striking aspect of this latter coverage was the extent to which local color was kept to a minimum: the bulk of the space was devoted to the great speeches noted in the previous section, where the heart of the Conservative case was expounded in detail.

The public's appetite was for enlightenment on national rather than local political affairs, and Smithson also contrived to establish a "Gazette Club" in each of Canterbury's five wards. ${ }^{103}$ Members, who were elected by a majority of the existing subscribers to ensure that only Conservatives joined, paid a weekly subscription of one penny. A team of six members read the current Gazette to the company in rotation; after the meeting, the paper circulated in the houses of members and was eventually sold off to anyone wishing to keep it. The proceeds, together with any surplus after the purchase of that week's Gazette, helped defray the expense of occasional club dinners. Reports of these dinners indicate attendances of between forty and sixty, suggesting, given five subdivisions, an audience of two to three hundred for the Gazette groups. ${ }^{104}$ Clearly the newspaper provided a focal point for local partisans, regardless of their ability to read the paper themselves, and a portal for connection to the wider "imagined community" of Conservatism. ${ }^{105}$

In Nottingham, a slightly different set of circumstances prevailed. The Constitutional Club here took direct responsibility for the education of local partisans through the provision of reading rooms. However, it is significant that the publisher of the town's leading Conservative newspaper, the Nottingham Journal, was at the heart of the party's activities in the locality. John Hicklin, a native of Nottingham and a churchwarden, was both the Honorable Secretary of the Nottingham Constitutional Club and, after 1835, a Councillor for the Sherwood ward. ${ }^{106}$ As was the case in Canterbury, the Journal carried long accounts of battles in the registration court, petitioning campaigns, and details of that "annual festival of personal animosity," the town council elections. ${ }^{107}$ Equally, there appeared detailed accounts of the principal speeches delivered at local dinners and the substance of pamphlets by local grandees such as the Duke of Newcastle. ${ }^{108}$

Hicklin also exploited his newspaper's position in the local political economy to provide his audience with special editions of particular speeches or meetings.

\footnotetext{
102 "Miscellany," piece 50, "Report of the speeches . . . to commemorate His Majesty's glorious declaration to support the constitution in church and state. . . Canterbury . . . Sept $25^{\text {th }} 1834$," (eight-page offering from Kentish Observer, price 6d.), BL, 1881 al, and "A Full report of the Grand Conservative Festival . . . July 17 $7^{\text {th }} 1835$ " (four pages, price 2d.), piece 52; Report of the Speeches delivered at the Fourth Anniversary Dinner of the Durbam Conservative Association (Durham, 1837).

${ }^{103}$ Kentish Gazette, 1 December 1835.

${ }^{104}$ See Kentish Gazette, 9, 16, and 23 February, 23 March, 5 and 26 April 1837; Barker, Newspapers, Politics and English Society, 53-56, for radical reading groups.

${ }^{105}$ The practice of reading newspapers and pamphlets aloud was common. Wilson, The Sense of the People, 69. The chairman of the Nottingham Operative Conservative Association reported to the Duke of Newcastle how impressed the membership had been by extracts read to them from His Grace's pamphlet and requested three copies for their reading room. N. P. Need to Duke of Newcastle, n.d. [c.1837], Newcastle Papers, Ne C 5458, NUL.

${ }^{106}$ Nottingham Journal, 28 October 1836; W. J. Butler to Lord Lincoln, 7 May 1839, Ne C 7781, NUL.

${ }^{107}$ Nottingham Journal, 4 November 1836

${ }^{108}$ Nottingham Journal, 20 March 1835, 19 June 1835, 31 July 1835, 17 June 1836; John Hicklin to Duke of Newcastle, 24 March 1837, Ne C 5446, NUL.
} 
The "Waterloo Dinner" held by the Nottingham Operative Conservative Association in June 1836 provided one example. "Finding it quite impossible to do justice to the . . . proceedings in the limits of our paper," the editor declared, "we have published a full report, including the powerful and brilliant speeches of Mr Wilkins, in a pamphlet, which is now ready, and may be had at our office, price one penny." ${ }^{109}$ Many other local dinners received similar treatment. ${ }^{110}$ Hicklin was equally sedulous in promoting the work of his party leader. In 1835, for example, the Nottingham Journal devoted two whole columns to Peel's great speech at the Merchant Taylor's Hall, and the proprietor commemorated his fall from power in April 1835 by making available a whole selection of his speeches. He reprinted Peel's famous address to the electors at Tamworth (price, ld.) and his speeches at the Mansion House in December 1834 (ld.), to the House of Commons on the address, and on the malt tax in 1835 ( $3 \mathrm{~d}$. each). Alongside this, he reprinted the speech at the Merchant Taylor's Hall in two separate editions, one priced at $2 \mathrm{~d}$., the other printed up as a handbill "price $1 \mathrm{~d}$ or $7 \mathrm{~s}$ per Hundred Copies." 111

Smithson and Hinckley were not unusual in the zeal with which they promoted the Conservative cause- or in their sense that there was a market for the political output of their respective presses. Across the country, local newspaper editors made it their business both to report the newsworthy doings of the local Conservative Association and to connect their readers with the wider ideals articulated by the national leaders of Conservatism. Peel's speeches, for example, were reproduced endlessly across the country: all local papers carried his speech at the Merchant Taylor's Hall, for example, and many reprinted it in cheap editions so that, as the editor of the Hampshire Advertiser remarked, it might "circulate . . . in all directions, by hundreds and by thousands, aye, and by tens of thousands." ${ }^{112}$ Many people would have encountered Peel's Tamworth Manifesto in this form, and the famous yet now strangely neglected speech delivered at the end of the 1836 session by Lord Lyndhurst provides another example. ${ }^{113}$ The speech, in which Lyndhurst defended the Conservative from the charge of simply "wrecking" Whig legislation and excoriated the government for its alliance with Daniel O'Connell, was reported widely in the press and republished in a variety of pamphlet forms thereafter. The British Library holds several versions: among them, a three-penny edition produced in Hull, and another emanating from London that went through at least six editions

\footnotetext{
${ }^{109}$ Nottingham Journal, 24 June 1836. They had earlier reprinted his speech to the Constitutional Club's annual dinner. Nottingham Journal, 17 June 1836. Wilkins had apparently been a reformer, which gave his impassioned speeches for the Conservative cause an added dimension. Nottingham Journal, 8 July 1836.

110 "Special supplement: Ashby de la Zouche Conservative Festival," Nottingham Journal, 23 December 1836.

${ }^{111}$ Advertisement, Nottingham Journal, 22 May 1835.

${ }^{112}$ Hampshire Advertiser, 23 May 1835; Derby Courier, 16 May 1835; Leicester Herald, 16 May 1835, 4. Many editions of Peel's Glasgow speech also appeared. Cleland, Description of the Banquet given in Honour of the Right Hon. Sir Robert Peel . . . on his Election as Lord Rector of the University of Glasgow (Glasgow, 1837); Revd G. Townshend to Duke of Newcastle, 12 April 1837, Ne C 5467, NUL.

${ }^{113}$ Quarterly Review cxiii, article xii, 230-70; William Sydney Gibson, A Memoir of Lord Lyndhurst (London, 1869), 43. The speech is rarely mentioned. Clark, Peel and the Conservative Party, 315-16; Dennis Lee, Lord Lyndhurst: The Flexible Tory (Niwot, CO, 1994), 205-6.
} 
and advertised discounts for bulk purchases. The pamphlet was available at $3 \mathrm{~d}$. per copy, 2s. $6 \mathrm{~d}$. per dozen, or 20s. per hundred for distribution, presumably by the new associations-further evidence, perhaps, that Conservatives recognized how far their cause depended not just on a restoration of "landed influence," but on winning the political argument. ${ }^{114}$

If the coverage of national political events in the local press provides one indication of the way in which the grassroots were tied into a wider debate, the readiness of the great national dailies to produce extensive reports of provincial dinners offers another. All the great newspapers did so, relying for their copy on a mixture of direct reporting, attributed reproduction from other newspapers, and, much more commonly, the unattributed précis of a longer report, sometimes rendered in the third person. The ubiquity of the practice makes it clear that the national papers considered the views expressed on such occasions to have a significance for contemporary readers that transcended locality. ${ }^{115}$ They were contributions to a genuinely national debate.

The intensity of coverage by the national dailies ensured that the Conservative message reached a broad audience. Whereas provincial newspapers like the Kentish Gazette and the Nottingham Journal, published weekly and circulated within welldefined areas, rarely sold more than two thousand copies each, The Times might sell up to forty thousand copies a day, each copy being read by as many as ten people. ${ }^{116}$ The sample of 115 local Conservative Association dinners used in the previous section provides a useful illustration of the potential impact of such coverage. By including accounts of dinners held not just in England but also in Scotland, Wales, and Ireland, and offering detailed reports of operative Conservative meetings alongside those of county and borough associations, The Times helped convince its readers that the revival was a genuinely nationwide phenomenon. ${ }^{117}$ Linda Colley has suggested that newspaper coverage during the Reform Bill crisis of 1831-32 gave radicals the sense that, whatever their local differences, "they were a single, unitary movement whose scope was Great Britain as a whole." ${ }^{118}$ It is likely that coverage in the national press ensured that a very similar "imagined community" developed among Conservatives after 1835. ${ }^{119}$

There seems little doubt that grassroots Conservatives were avid consumers of the speeches reproduced in the press. The list of the newspapers taken by the reading room in Nottingham certainly gives a sense of how broad the local encounter with the larger Conservative worldview might be. In 1836, the association

${ }^{114}$ Speech of the Rt. Hon Lord Lyndhurst delivered in the House of Lords on Thursday August 18, 1836 (Hull, 1836); Summary of the Session: Speech of the Right Hon. Lord Lyndhurst, delivered in the House of Lords on Thursday August 18, 1836 (London, 1836).

${ }^{115}$ Spirit of the Metropolitan Conservative Press; Being a Selection of the best leading articles from the London Conservative Journals during the Year 1839, 2 vols. (London, 1840), 1:x. Ian Newbould suggests the ministerial press was less successful in sustaining popular attention (Whiggery and Reform, 1830-1841: The Politics of Government [Basingstoke, 1990], 34-38).

${ }^{116}$ Barker, Newspapers, Politics and English Society, 34; The History of The Times, 3 vols. (London, 1935-39), 1:332, 412, 498-99.

117 The Times, 19 September 1836, 3 (E. Riding; Broadley).

${ }^{118}$ Colley, Britons, 339.

119 David Close, "The Formation of a Two-Party Alignment in the House of Commons between 1832 and 1841," English Historical Review 84, no. 331 (1969): 268-69; Read, Peel and the Victorians, 44-56; The Times, 19 December 1835, 3 (Birmingham; Dugdale). 
took three copies of the Standard and one each of The Times, Morning Post, Morning Herald, Globe, and Sun. ${ }^{120}$ Among the weekly titles were the Record, John Bull, and the Age, as well as leading provincial titles from Yorkshire, Leicester, Liverpool, Derby, and Manchester. The local Nottingham titles were also taken.

What readers consumed clearly shaped their outlook thereafter. ${ }^{121}$ Newspapers broke down the barriers of time and space that separated individual Conservatives. ${ }^{122}$ As one contemporary remarked, "The 'Morning Chronicle' is printed and published every morning, that I may know what news is stirring abroad and at home: if I am wrong in any political opinion, the editor sets me right: if I am indifferent to party, he rouses me up, and makes me a partisan. In the House Sir Robert Peel pretends to address himself to the Speaker, but it is to me that he speaks-it is me that he endeavours to convince." ${ }^{123}$ The sense of personal communication between the great national figures and their local followers was tangible, and members of the Conservative Associations identified themselves closely with the utterances of their leaders. Lyndhurst's impassioned defense of the House of Lords was endlessly quoted at Conservative Party dinners in the autumn of 1836, for example, only to be displaced by Peel's unequivocal backing for the Church of England at Glasgow University in January $1837 .{ }^{124}$

The corollary of this heightened sense of correspondence between leaders and led was that grassroots Conservatives saw themselves as part of a genuinely national movement roused in defense of the constitution in church and state. Speakers frequently "proved" the strength of Conservative reaction in the country, as did the President of the Hull Conservative Society, by pointing out that "the newspapers teem with accounts of similar meetings throughout the country at large."125 Equally, the sense of national community fostered by the press ensured that Conservatives in all parts of the country celebrated the party's triumphs in any locality with similar fervor. ${ }^{126}$ The defeat of Lord John Russell in South Devon on retaking office in 1835, for example, was universally hailed by Conservatives. The editor of the Hampshire Advertiser struck the chord of brotherhood, declaring "Men of Devonshire, we thank you-we honour you-we rejoice with you"; days later, a letter from Mr. Parker, the victorious candidate, thanking the Nottingham Constitutional Club's members for their congratulations, "excited the loudest plaudits" when it was read out, and at its conclusion "three times three hearty cheers were given." 127 The "enthusiastic cheering" of a Conservative audience in Norfolk at the toast "our friend and brother Conservative Mr Parker, member for South Devon, and the glorious majority of 627" was echoed as far away as Durham and

\footnotetext{
${ }^{120}$ Nottingham Journal, 17 June 1836.

${ }^{121}$ Brett, "Political Dinners," 529.

${ }^{122}$ Benedict Anderson, Imagined Communities (London, 1983).

${ }^{123}$ Cornelius Webbe, Glances at Life in City and Suburb (London, 1836), quoted in Quarterly Review cxiii, article XI, 223-29.

${ }^{124}$ The Times, 24 October 1836 (E. Worcestershire; Lord Redesdale); The Times, 2 September 1836 (Denbighshire; Kenyon); The Times, 10 September 1836 (S. Lancashire; Lord Skelmersdale); The Times, 27 October 1836 (Leeds; Beckett); The Times, 27 January 1837 (S. Warwickshire); Kentish Gazette, 24 January 1837 (Maidstone; Knatchbull).

${ }^{125}$ The Times, 19 September 1836 (E. Riding; Broadley); The Times, 24 September 1836, 7 (Wicklow; Fitzwilliam).

${ }^{126}$ The Times, 8 November 1836 (Devonport; Dawson); The Times, 20 October 1836 (Liverpool).

${ }^{127}$ Hampshire Advertiser, 9 May 1835.
} 
the East Riding. ${ }^{128}$ Newspaper coverage ensured that these were triumphs in which all shared. ${ }^{129}$

The press thus played a crucial role in connecting the roles of local and national politics. The associations were cast as parts of a chain that would "serve as an effectual barrier against any encroachments and any attacks on the fundamental principles of the British constitution," and the coverage of their activity created a coherent narrative context within which local activism could be understood. ${ }^{130}$ In the absence of any central party direction, it is arguable that it was the coverage offered by the national press that supplied local Conservatives with a sense of their party's unity and extent.

This article has suggested that political life in the locality was heavily infused by a concern for "national" political issues and an enthusiastic engagement with "national" political identities in the later 1830s. The crisis precipitated by the king's dismissal of his Whig ministers created the conditions for an unprecedented realignment of political forces around the moderate reforming figure of Sir Robert Peel, both within parliament and in the country at large. His Macaulayite notion that accepting moderate reform was the surest means of preserving intact the constitution in church and state brought together a broad alliance of moderate Whigs and Tories. The crucial agents in cementing the realignment, it has been argued, were the Conservative Associations and the press: the first educated local opinion and rendered it politically effective through the process of registration, while the second helped universalize the central tenets of the Conservative credo and allowed local actors to identify with the unfolding drama of national politics. In the reform decade, "politics" was not something encountered only during the topsy-turvy days of a contested election: it was a constant presence, something to be committed to, subscribed to, something for which individuals felt compelled to take responsibility.

By extending inquiry beyond the narrow confines of contested elections, therefore, it is clear that national issues and national party alignments mattered at the grassroots level in the 1830s. It would be wrong to end, however, without entering a note of ambiguity concerning the larger question of the Reform Act's modernizing impact on British politics. While many of the structures it put in placenotably, annual registration - had the potential to embed political identities more deeply at constituency level, the intense correspondence between national and local politics evident in the 1830s did not endure. This was in large part because the "national" identities themselves proved so unstable, especially after the Conservative split over Corn Law repeal in 1846. The fragmented landscape of the 1850 s and 1860s made the work of local registration bodies very difficult: without

\footnotetext{
${ }^{128}$ The Times, 11 May 1835 (E. Norfolk; Browne); The Times, 16 January 1836 (Durham; Londonderry); The Times, 19 September 1836 (E. Riding; Bethell).

${ }^{129}$ Nottingham Journal, 5 June 1835.

130 "Conservative Associations: Croydon," The Times, 2 May 1835; The Times, 3 November 1838 (E. Worcestershire; Paul); see also The Times, 10 September 1836 (S. Lancashire); The Times, 14 November 1836 (Blackburn Operatives; chairman's speech); The Times, 27 January 1837 (S. Warwickshire; Shirley); The Times, 28 January 1839 (Ashby de la Zouche; Manners).
} 
a clear cause, it was difficult to know who or what voters were registering for and correspondingly difficult to persuade local partisans to put their hands in their pockets to pay for the process. ${ }^{131}$ Many associations-such as that in Hertfordshire-were wound up in the early 1850s, and with their demise the registers were neglected: the simple knowledge of who was, and who was not, to be counted a political "friend" disappeared. ${ }^{132}$ Far fewer candidates were prepared to risk an expensive election in such circumstances, and the number of contests-particularly in county seats-declined sharply as a consequence. ${ }^{133}$ The loss of the associations also meant that the focal point for newspaper linkage of local and national politics had been removed. The editorials and leading articles remained as bombastic as ever, but without the associations, there was no local sounding board for these opinions.

In the absence of nationally defined partisanship, local reference points and personalities reasserted themselves in many areas. Only with the revival of serious extraparliamentary interest in constitutional reform during the early 1860s did national and local politicians rediscover a common focus for sustained two-party partisanship. This time, the alignment proved more enduring.

\footnotetext{
${ }^{131}$ The Leeds Conservative Association was reported to have died a "natural death" from lack of funds in 1847. Liverpool Mercury, 22 January 1847.

${ }^{132}$ Granville D. Ryder to Longmore, 28 January 1853, D/EL B566, 5965/63, Herts. RO.

${ }^{133}$ See Cragoe, Culture, Politics and National Identity, 66-68, for a demonstration of this trend in Wales.
} 